\title{
Corporate Social Responsibility, Size, and Tax Aggressiveness: An Empirical Analysis
}

\author{
R. A. H. Rahmat (Author) \\ Universitas Pendidikan Indonesia \\ Bandung, Indonesia
}

\author{
M. Kustiawan \\ Universitas Pendidikan Indonesia \\ Bandung, Indonesia
}

\begin{abstract}
Corporate social responsibility (CSR) and taxes have the same roles and functions for social welfare, but large companies in Indonesia often use CSR to reduce taxes. This study examines the relationship between corporate social responsibility (CSR), firm size and corporate tax aggressiveness. Researchers used samples from 11 public companies listed in LQ45 Indonesia for financial year 2013-2015. The results of multiple regression analysis show that there is no evidence for a significant relationship between corporate CSR activities and corporate tax aggressiveness, while the size of the company has an influence on corporate activities in con-ducting corporate tax aggressiveness.
\end{abstract}

\section{Keywords-CSR; Firm Size; Tax Aggressiveness}

\section{INTRODUCTION}

The Indonesia's main income comes from the tax sector. Tax sources in Indonesia come from individual and corporate taxpayers. Indonesia has many companies that belong to corporate taxpayer from various sectors of industry. The greater income make the greater tax paid by the company [1]. Companies are required to minimize corporate taxes through tax aggressiveness activities. Tax aggressiveness is a common thing for companies around the world. The public's view of companies that engage in tax-aggressive acts is deemed to have constituted a socially unlawful and socially irresponsible activity [2]. In the Indonesia Law no. 40 of 2007 article 74 on social and environmental responsibility, it is written that "Companies which carry out their business activities in the field and / or related to natural re-sources shall be obligated to carry out Social and Environmental Responsibility". Another term for corporate responsibility is Corporate Social Responsibility [1]. Corporate Social Responsibility is about how companies manage business processes to generate an overall positive impact on society [3]. A new study suggests that the CSR factor significantly affects corporate tax aggressiveness through the board of directors. They argue that outside directors are more responsive to community needs and therefore expected to influence the board of directors in aggressive tax policies [2]. In a much broader and arguably more important context, CSR has the potential to influence tax aggressiveness in terms of how the company directs its systems and processes with respect to the well-being of society as a whole [4]. However, there are conflicting studies that say corporate social re-sponsibility (CSR) has no effect on tax aggressive-ness. CSR activities do not affect companies to min-imize tax payments [1]. Another study shows that the quality of CSR has a negative effect on tax avoidance.
Companies with good CSR quality tend to experience a reduction in tax avoidance [6].

Besides aspects of CSR, the size of the company is also one of the causes of aggressive taxation. This is because the larger the company, the greater the re-sources owned by the company to manage its tax burden [4]. But there is al-so research that states the size of the company does not affect the aggressiveness of taxes because the company assumes that the tax paid is a burden that will reduce the expected profit so that companies use the existing loopholes to carry out tax avoidance [7].

Based on the explanation above, there are differences in research results between CSR, size and tax aggressiveness. Researchers want to research in Indonesia in 2013 until 2015 the relationship CSR, size and tax aggressiveness.

\section{A. Stakeholder theory}

In general, stakeholder theory suggests that firms are not only responsible for the welfare of the enterprise, but must have social responsibilities taking into ac-count the interests of all parties affected by the company's strategy actions or policies. The success of a company depends largely on its ability to balance the diverse interests of its stakeholders or stakeholders [8].

\section{B. Theory of legitimacy}

Legitimacy Theory is a theory that focuses on the interaction between companies and stakeholders. Companies need legitimacy or recognition from investors, creditors, consumers, government and society in order to maintain its survival. For the legitimate company of society can be obtained if the company performs social responsibility [9]. Corporate awareness that the survival of the company is very dependent on the company's relationship with society and the environment, then in accordance with the theory of legitimacy companies are required to be able to perform its activities in accordance with the values of justice and limitations norms prevailing in society

\section{The influence of social responsibility disclosure against tax aggressiveness}

Corporate Social Responsibility according to is about how companies manage business processes to generate a positive overall impact on society [3]. A new study suggests that the CSR factor significantly affects corporate tax aggressiveness 


\section{Variables}

This study uses the dependent variable of tax aggressiveness. Tax aggressiveness is a corporate strat-egy that is not in line with community expectations [2]. There is no universally accepted definition of tax aggressiveness [14]. Tax aggressiveness as a tax planning activity of all firms involved in reducing effective tax rates [15]. It can be concluded that tax aggressiveness is part of tax management in terms of tax planning. Where, if associated with tax avoidance or embezzlement, tax planning aggressiveness leads more to tax avoidance that is included in legal action in an effort to reduce the tax payable by the company. However, there is a distinction between tax avoidance and tax aggressive-ness in the activity of tax planning aggressiveness to reduce tax indebted with more aggressive. This study used ETR proxies according to the proxies used in previous studies [2]. ETR formula consists of income tax expense and in-come before tax.

$$
\text { ETR }=\frac{\text { Tax Expense }}{\text { Earning Before } \operatorname{Tax}}
$$

The independent variables used in this study con-sist of CSR disclosure and firm size. CSR disclosure measured by CSR Disclosure Index proxy (CSRI) refers to the GRI (Global Reporting Initiatives) dis-closure indicator. GRI as the holder of authority on sustainability report in the world, has developed a framework for sustainability reporting including CSR disclosure indicators. GRI requires companies that use the G3 Guidelines to meet the types of re-porting standards of organization profile, organizational indicators and management approach The number of CSR disclosure items by GRI is 84 which consists of economics (9 items), environment (34 items), labor practices work (16 items), human rights (12 items), social (11 items) and product responsibility (10 items). To measure it used content analysis method as used in research. Each CSR item in a re-search instrument is rated 1 if it is disclosed and a value of 0 if it is not disclosed. Furthermore, the score of each item is summed to get the overall score for each company. The CSRI calculation formula is as follows [16]:

$$
C_{S R I_{J}}=\frac{\sum X_{i j}}{n_{j}}
$$

where CSRIJ = corporate social responsibility disclosure index; $\mathrm{nj}=$ the number of items for the company; $\mathrm{XiJ}=$ dummy variable; $1=$ if item $i$ is expressed; $0=$ if item $i$ is not disclosed.

Variable Company size is measured here using the total assets owned by the company obtained from the company's annual financial statements for 2012-2014. This measurement method based on measurements [13].

$$
\mathrm{SIZE}=\log (\text { total Asset })
$$

\section{RESULT AND DISCUSSION}

\section{A. Classic assumption test}

The classical assumption test used in this study includes normality test, multicolonierity test, hetero-scedasticity test, and autocorrelation test. In the normality test can be done by looking at the significance of Kolmogrorof-Smirnov (K-S), from the data table above is known significance value of 0.200 is greater than 0.05 which means that the data in this study is 2015).

- Companies that had complete data related to the variables to be used in this study.

33 samples taken are 11 companies for 3 years (2013- 
normally distributed. In multicollinearity test can be said free from multicollinearity seen from tolerance value $>0,10$ and VIF $<10$ from table above seen tolerance value and VIF fulfill criterion. The level of significance of these variables is above $5 \%$ or 0.05 , therefore it can be concluded that the regression model is free from the assumption of heteroscedasticity. Symptoms of autocorrelation can be detected using the DurbinWatson (DW) test. From Durbin-Watson (DW) test it is known that the value of 1,885 with the criterion of DW value between -2 and 2. Then this means there is no autocorrelation (see Table 2).Before you begin to format your paper, first write and save the content as a separate text file. Keep your text and graphic files separate until after the text has been formatted and styled. Do not use hard tabs, and limit use of hard returns to only one return at the end of a paragraph. Do not add any kind of pagination anywhere in the paper. Do not number text headsthe template will do that for you.

TABLE 1 CLASSIC ASSUMPTION TEST.

\begin{tabular}{|l|c|c|c|c|c|c|}
\hline & \multicolumn{2}{|l|}{$\begin{array}{l}\text { Normali } \\
\text { ty Test }\end{array}$} & \multicolumn{2}{c|}{$\begin{array}{c}\text { Multicolonier } \\
\text { ity } \\
\text { Test }\end{array}$} & $\begin{array}{c}\text { Heteroscedasti } \\
\text { sity } \\
\text { Test }\end{array}$ & $\begin{array}{c}\text { Autocorrelat } \\
\text { ion test }\end{array}$ \\
\hline & Z & P & Tolerance & VIF & Sig & DW \\
\hline $\begin{array}{l}\text { Unstandardi } \\
\text { zed Residual }\end{array}$ & 0.093 & 0.200 & & & & \multirow{2}{*}{1.885} \\
\hline CSR & & & 0.760 & 1.317 & 0.190 & \\
\cline { 1 - 4 } SIZE & & & 0.760 & 1.317 & 0.051 & \\
\hline $\begin{array}{l}\text { Durbin- } \\
\text { Watson }\end{array}$ & & & & & & \\
\hline
\end{tabular}

\section{B. Hypothesis testing}

TABLE 2. SUMMARY OF PARAMETER MODEL ESTIMATION RESULTS Y

\begin{tabular}{|c|c|c|c|c|c|c|c|}
\hline Model & $\mathbf{R}$ & $\begin{array}{c}\mathbf{R}^{2} \\
\text { (Adjusted } \mathbf{R}^{2} \text { ) }\end{array}$ & $\mathbf{R}^{2}$ Change & $\mathbf{B}$ & $\mathbf{S E}$ & $\mathbf{B}$ & $\mathbf{T}$ \\
\hline Model 1 & .529 & $.279(.231)$ & & & & & \\
\hline Constan & & & & -.930 & .200 & & -4.650 \\
\hline CSR & & & -.080 & .053 & -.267 & -1.502 \\
\hline SIZE & & &.,$- 083 *$ & .024 & $-.605 *$ & -3.405 \\
\hline $\begin{array}{l}* * * \text { Significance at the } 0.01 \text { level; ** Significance at the } 0.05 \text { level; * } \\
\text { Significance at the 0.1 level }\end{array}$ \\
\hline
\end{tabular}

Based on Table 3 analysis of determination coef-ficient obtained adjusted R Square amounted to 0.279, which means that for $27.9 \%$ variable tax ag-gressiveness (ETR) will be influenced by independ-ent variables. While the rest is influenced by other variables that are not included into this study. That the regression model built has met the fit model criteria that the F-statistic probability value is 0.007 less than 0.05 , so the regression model can be used to predict the dependent variable that is tax aggressive-ness. Based on Table 3 , when associated with the hypothesis test that the authors propose to have the meaning as follows:

- CSR variable shows no significant effect on tax aggressiveness (ETR). This is indicated by the significance value of $0.144>0.05$ then $\mathrm{HO}$ is re- jected. So it can be concluded that CSR partially has no effect on tax aggressiveness (ETR).

- SIZE variables show significant effect on tax aggressiveness (ETR). This is indicated by the significance value of $0.002<0.05$ then $\mathrm{H} 0$ is rejected. So it can be concluded that SIZE partial-ly affect the return tax aggressiveness (ETR).Finally, complete content and organizational editing before formatting. Please take note of the following items when proofreading spelling and grammar:

Based on the empirical results that exist in the pro-cess, the CSR activities carried out by the company have no effect on the activities of tax aggressiveness, meaning that every company that carries out CSR activities has no purpose in the case of tax. Aggressiveness, this is possible because companies take that are related to CSR purely because of efforts to increase the value of the company. Other than that CSR activities are due. The results of this study sup-port the results of the study [1] and [6] which states that the quality of corporate social responsibility (CSR) is not beneficial to the tax aggressiveness. CSR activities do not affect companies to pay taxes. There are several studies that contradict the results of a research that states that companies always state that the CSR burden and tax bur-den are costs that must be paid by the company [17]. In principle, the CSR and Tax burden has a purpose for public welfare. So that companies do not pay taxes that are too large to start efforts to reduce taxes. This aggression is carried out by carrying out additional CSR than before, which will generate a burden with CSR. Of course this action is not in line with people's expectations.

\section{REFERENCES}

[1] Jessica, J. \& Toly, A.A. 2014. Pengaruh pengungkapan corpo-rate social responsibilty terhadap agresivitas pajak. Tax \& Accounting Review 4(1).

[2] Lanis, R. \& Richardson, G. 2011. The effect of board of direc-tor composition on corporate tax aggressiveness. Journal of Accounting and Public Policy 30(1): 50-70.

[3] Baker, M., Stein, J.C. \& Wurgler, J. 2003. When does the mar-ket matter? Stock prices and the investment of equity-dependent firms. The Quarterly Journal of Economics 118(3): 969-1005.

[4] Desai, M.A. \& Dharmapala, D. 2006. Corporate tax avoidance and highpowered incentives. Journal of Financial Eco-nomics 79(1): 145-179.

[5] Tjondro, E., Widuri, R. \& Katopo, J.M. 2016. Kualitas corpo-rate social responsibility dan penghindaran pajak dengan kinerja laba sebagai moderator. Jurnal Akuntansi dan Keuangan 18(2): 105-118.

[6] Tandean, V.A. 2016. Pengaruh tax avoidance terhadap nilai perusahaan dengan profitabilitas sebagai variabel pemoderasi. Proceeding SENDI_U.

[7] Lako, Andreas. 2011. Dekonstruksi CSR \& reformasi para-digma bisnis dan akuntansi. Jakarta: Erlangga.

[8] Hidayati, N. \& Fidiana. 2017. Pengaruh corporate social re-sponsibility dan good corporate governance terhadap penghindaran pajak. Jurnal Ilmu Dan Riset Akuntansi Tinggi Ilmu Ekonomi Indonesia (STIESIA) Surabaya, 6.

[9] Kurniasih, T. \& Sari, M.M.R. 2013. Pengaruh return on assets, leverage, corporate governance, ukuran perusahaan dan kompensasi rugi fiskal pada tax avoidance. Jurusan Akuntansi, Fakultas Ekonomi, Universitas Udayana 18(1): 58-66.

[10] Ngadiman, N. \& Puspitasari, C. 2014. Kepemilikan institusion-al, dan ukuran perusahaan terhadap penghindaran pajak. Jurnal Akuntansi XVIII(03): 408-421. 
[14] Hlaing, K.P. 2012. Organizational architecture of multina-tionals and tax aggressiveness. University of Waterloo.

[11] Darmawan, I.G.H. \& Sukartha, I.M. 2014. Pengaruh penera-pan corporate governance, leverage, return on assets dan ukuran perusahaan pada penghindaran pajak. E-Jurnal Akuntansi Universitas Udayana 1: 143-161.

[12] Surbakti, T.A.V. 2012. Pengaruh karakteristik perusahaan dan reformasi perpajakan terhadap penghindaran pajak di pe-rusahaan industri manufaktur yang terdaftar di bursa efek Indonesia tahun 2008-2010. Skripsi. Universitas Indone-sia. Depok.

[13] Balakrishnan, K., Blouin, J.L. \& Guay, W.R. 2011. Does tax aggressiveness reduce financial reporting transparency?. SSRN Electronic Journal (215).

[15] Haniffa, R.M. \& Cooke, T.E. 2005. The impact of culture and governance on corporate social reporting. Journal of Ac-counting and Public Policy 24(5): 391-430.

[16] Setiadji, B. 2010. Diusulkan ada pemotongan pajak. Harian Seputar Indonesia. Retrived http://www.ortax.org. Accessed 9 Januari 2018.

[17] Lanis, R. \& Richardson, G. 2014. Is corporate social responsi-bility performance associated with tax avoidance?. Jounal Business Ethics. 